Niepełnosprawność. Dyskursy pedagogiki specjalnej

Nr 32/2018

Disability. Discourses of special education

No. 32/2018

\title{
Dorota Krzemińska
}

Uniwersytet Gdański

\section{"My business" - experimental performance about love, being a couple and pregnancy of people with Down Syndrome. The artistic work of theatre company of adults with intellectual disabilities as the right to (co-creating) culture - a sketch}

The presented text aims to show how the experience of love, being a couple, pregnancy is performed in the artistic work of theatre company of adult people with intellectual disabilities. Particularly I concentrate on the theatre company BRO which conducted a kind of priming experimental performance entitled "My business". The experimental nature of the performance means it was conducted in collaboration with professional script writer, scene artist, music composer and most especially professional actors, who perform on stage together with actors with Down Syndrome/intellectual disabilities. The text is focused on the performance "My business" and attempts to show how art - performances of theatre companies of people with intellectual disabilities - creates a space in which they could show how they see love, relationships between women and men, parenthood/pregnancy and how they function and ?nd themselves in a social context. Theoretical inspiration for the discussion is theory of dialogue and carnivalization by M. Bakhtin. Art and performances serve as a perfect tool to change meanings ascribed to people with intellectual disabilities: either to their needs and ability to love, being a couple, experience of parenthood or to their creative output that could be negotiated and altered. They also convince that people with intellectual disabilities not only have the right to (access, participate and create) culture but simply are a part of it.

Keywords: adults with intellectual disabilities, love, being a couple, sexual needs, pregnancy, art/ performances/ theatre companies

\section{„Moja sprawa” eksperymentalny spektakl o miłości, byciu parą i ciąży osób z zespołem Downa. Twórczość artystyczna teatrów osób z niepełnosprawnością intelektualną jako prawo do (współtworzenia) kultury - szkic}

Prezentowany tekst jest próbą pokazania tego, w jaki sposób doświadczenie miłości, bycia parą, ciąży jest przedstawiane w spektaklu z udziałem osób dorosłych z niepełnosprawnością intelektualną. W szczególności tekst koncentruje się na sztuce „Moja sprawa” wystawionej przez grupę Biuro Rzeczy Osobistych. Jest to spektakl eksperymentalny, co oznacza, iż został wyreżyserowa- 
ny przez profesjonalnego reżysera, wykreowany z udziałem profesjonalnego scenarzysty, scenografa, kompozytora muzyki, przede wszystkim zaś, z udziałem zawodowych aktorów, którzy występują na scenie razem z aktorami z zespołem Downa/ niepełnosprawnością intelektualną. Artkuł stanowi dyskusję nad rolą sztuki jako przestrzeni, w której możliwe jest przedstawienie ((zagadnienia / problemu) miłości, relacji pomiędzy kobietami i mężczyznami z niepełnosprawnością intelektualną, ciąży i rodzicielstwa jako zjawisk rozgrywających się w przestrzeni społecznych relacji i uwikłań. Kontekst teoretyczny dla dyskusji stanowi teoria dialogu i karnawalizacji M. Bachtina. Sztuka, spektakl, teatr wydają się znakomitym miejscem, w którym dokonywać może się zmiana znaczeń przypisywanych osobom z niepełnosprawnością intelektualną, zarówno odnoszących się do ich doświadczeń związanych z byciem parą, seksualnością, ewentualnością ciąży i rodzicielstwa, jak i znaczeń, które dotyczą ich potencjału twórczego, który wskazuje na to, że osoby te mają nie tylko prawo do kultury ( dostępu, uczestnictwa, tworzenia) kultury , ale są jej częścią.

Słowa kluczowe: dorośli z niepełnosprawnością intelektualną, miłość, bycia parą, potrzeby seksualne, ciąża, sztuka, spektakl teatralny.

\section{Introduction}

In the paper I attempt to see and reflect on some chosen pieces of artistic work of people with intellectual disabilities which could be seen and interpreted in the context of art and (participation and co-creating) culture. I want to show how the experience of love, being a couple, pregnancy is performed in the artistic work of theatre company of adult people with intellectual disabilities. Particularly I concentrate on the theatre company BRO Biuro Rzeczy Osobistych - Personal Items Office which conducted a kind of priming experimental performance entitled "My business". The experimental nature of the performance means it was conducted in collaboration with professional script writer, scene artist, music composer and most especially professional actors, who perform on stage together with actors with Down Syndrome / intellectual disabilities.

The presented considerations are focused on the performance "My business" and derived from selected empirical data collected during open in-depth interviews, ethnographic interviews and participant observations which provide examples firmly rooted in the social experience of the company's members, their collaborators and the audience. However, in the presented text, which is only a kind of a sketch, I mainly concentrate on the idea how art - performances of theatre companies of people with intellectual disabilities - creates a space in which they could show how they see love, relationships between women and men, parenthood/pregnancy and how they function and ?nd themselves in a social context.

Theoretical inspiration for the discussion is theory of dialogue and carnivalization by M. Bakhtin [e.g. S. Dentith 1995; Polly Bugros Mclean, David Wallace, https://ijoc.org/index.php/ijoc/article/viewFile/1698/947]. Art and performances serve as a perfect tool to change meanings ascribed to people with intellectual disabilities: either to their needs and ability to love, being a couple, experience of par- 
enthood or to their creative output that could be negotiated and altered. They also convince that people with intellectual disabilities not only have the right to (access, participate and create) culture but simply are a part of it.

In my paper I attempt to reflect on the process of creating a personal, social, and cultural space that allows disability to emerge as a phenomenon defined in terms of socio-cultural potency and ability, and not as a deviation from an arbitrary norm (i.e. as dis-ability). Yet the analysis will focus on selected aspects of the artistic work of a particular theatre company from Tricity, which consists of adult people who were clinically diagnosed with low-functioning intellectual disabilities and their activities are connected with Polish Association for Persons with Intellectual Disabilities. The theatre group named Biuro Rzeczy Osobistych - Personal Items Office has been running for eighteen years under the direction of Zbigniew Biegajło - pedagogue, therapist, director. The company has realized a few important social - artistic projects and has taken part not only in various disability arts festivals, but also arts festivals of alternative or off theatres and it finds itself in a very special place now. The company has managed to change the perception of the art of people with disabilities and has come close to achieving the goal they set before them - turning professional. Not only would this be the crowning of their achievements, but also the final step of their departure from the therapeutic context determined by the medical model of disability ${ }^{1}$.

\section{1. "My business"}

What I want to mainly concentrate on is a recent performance of the ensemble entitled "My business" which is devoted to the relationship between woman and man with Down syndrome, exposing the problem of pregnancy, they both - together with their relatives experience. It's a drama constructed as a theatre in the theatre, which tells the story about a woman with Down syndrome who is an

\footnotetext{
The very first time "My business" was mentioned and discussed during The International Conference "Nagotiating Space for (Dis)ability in Drama, Theatre, Film and Media", Department of Studies in Drama and Pre - 1800 English Literature, University of Łódź, 25-27.09.2015. Both with Jolanta Rzeźnicka-Krupa we gave a speech on: "Between Therapy and Art - Borderline Space in Thetatre of People with Intellectual (Dis-)Ability, considering art and theatre companies of people with intellectual disabilities functioning in Tricity. After the conference presentation we were proposed by the organizers to write a chapter in a monography: „Disability and Dissensus: Strategies of Disability Representations and Inclusion in Contemporary Culture", (eds.) K. Ojrzyńska, M. Wieczorek. The text entitled "Between Therapy and Art - Borderline Space in Thetatre of People with Intellectual (Dis-)Ability was translated into English by K. Ojrzyńska and M. Wieczorek and the monography is being proceeded in Manchester University Press. The presented text is a detailed version of my individual speech and presentation during $7^{\text {th }}$ Annual Conference of ALTER, European Society for Disability Research, Transforming practices and knowledge through the lens of disability: experiences, transmissions, training, organizations at the Université Catholique de Lille, 5-6.07.2018.
} 


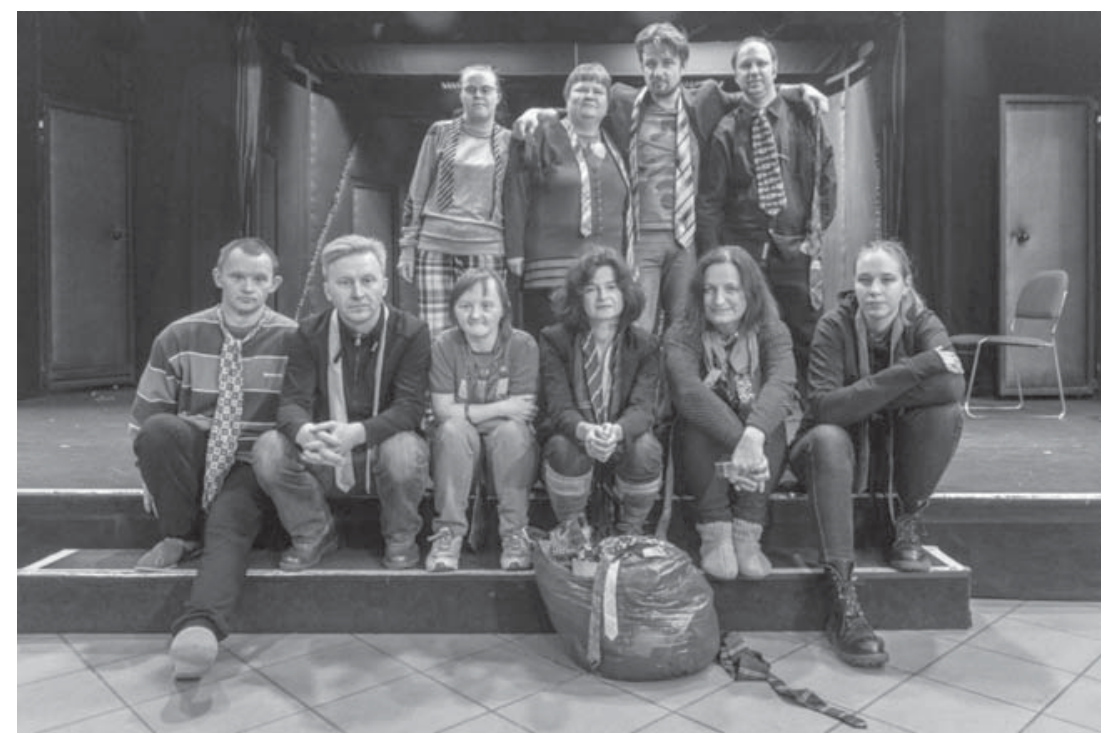

Photo 1. Biuro Rzeczy Osobistych - Personal Items Office, „My business”, rehearsals Standing from the left: Oliwia Cubala, Renata Klinkosz, Krzysztof Grabowski, Adam Siekierzyński. Sitting from the left: Marcin Wenta, Zbigniew Biegajło, Marzena Gajewska, Iwona Siekierzyńska, Izabela Stronia.

Source: photo by Maciej Czarniak / trójmiasto.pl.

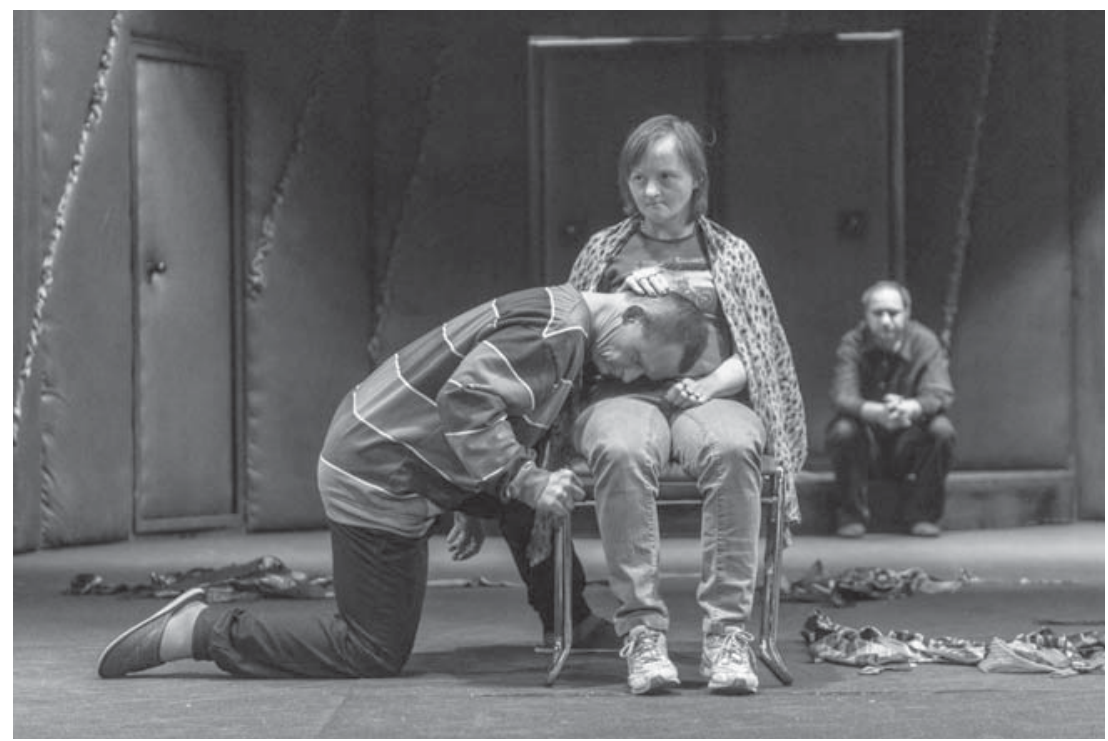

Photo 2. Rehearsals, the main characters of "My business" - Marzena Gajewska as Wiktoria, Marcin Wenta as Adam. In the background - Adam Siekierzyński

Source: photo by Maciej Czarniak / trójmiasto.pl. 
actress of an ensemble and who - while working on the performance and rehearsals gets pregnant with a man with Down syndrome. This fact eventually triggers a series of tragical and stirring events, perfectly showing a very complicated and dramatic situation of a woman with Down syndrome herself and also her mother who rises and cares for her adult daughter alone. The important characters of the play are: partner of a woman with whom she gets pregnant, who is also a man with Down syndrome and the theatre group instructor and gynecologist. All actors' role playing vividly bring to light how the phenomenon of being a couple with intellectual disabilities and pregnancy is viewed and perceived within the social, institutional and family context, as well as in the context of personal dependence, loneliness, internal and moral tearing.

\section{Why do we call "My business" experimental?}

The experimental nature of the performance is the cast - it consists of actors with intellectual disabilities (Personal Items Office - BRO) and professional and popular actors. The script, music, scenery and costumes were made by professionals and the performance was conducted by a professional director [Cast: director Iwona Siekierzyńska, script writer Radosław Paczocha, music composer Marzena Majcher, costumes and scenery Izabela Stronias and professional actress Aleksandra Nieśpielak and actor Krzysztof Grabowski.

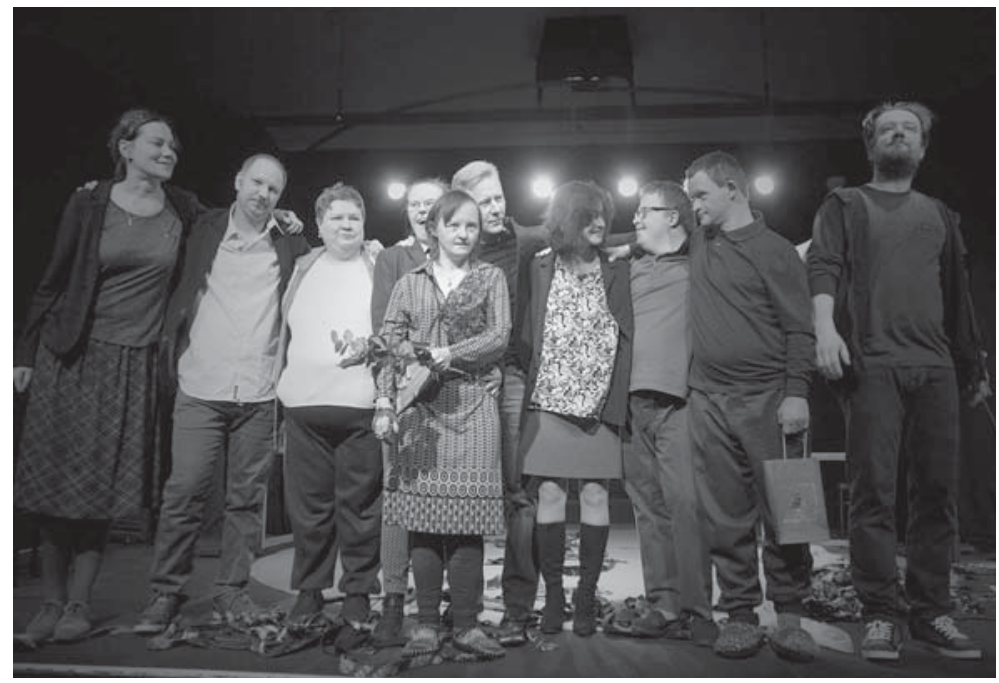

Photo 3. "My business" - premiere. Standing from the left: Aleksandra Nieśpielak, Adam Siekierzyński, Renata Klinkosz, Oliwia Cubala, Marzena Gajewska, Zbigniew Biegajło, Iwona Siekierzyńska, Tomasz Macniak, Marcin Wenta, Krzysztof Grabowski Source: photo by Piotr Wittman. 


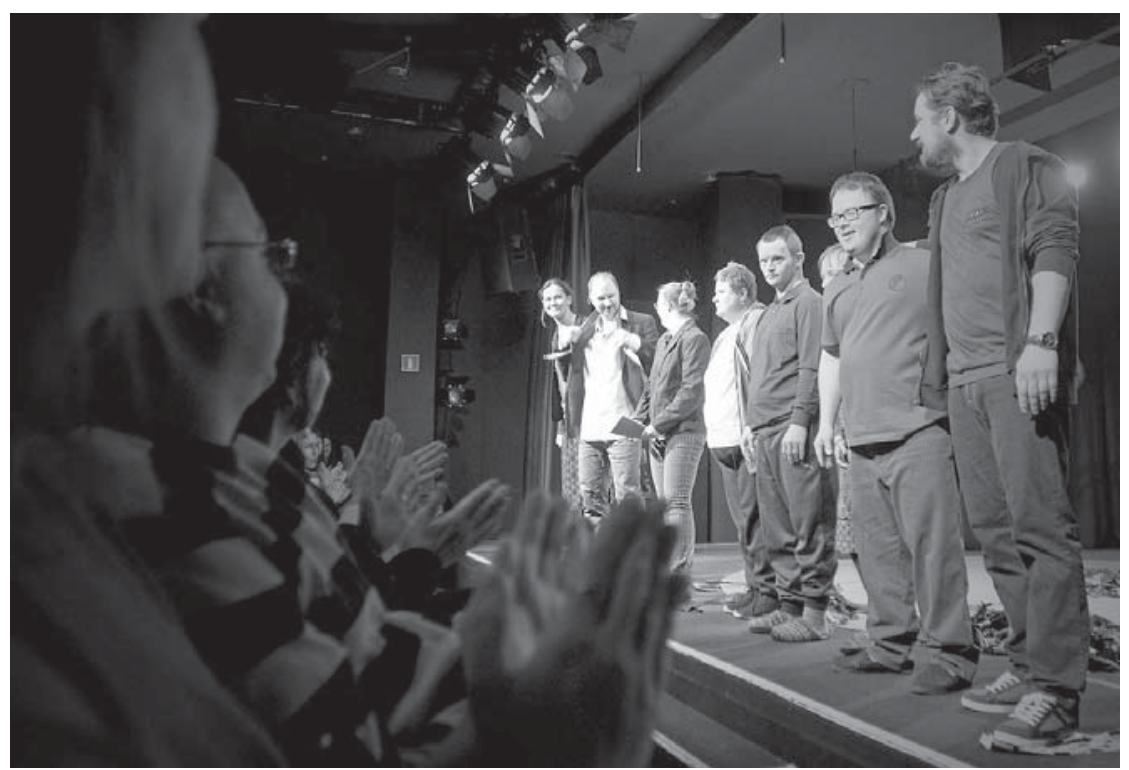

Photo 4. "My business" - premiere

Source: photo by Piotr Wittman.

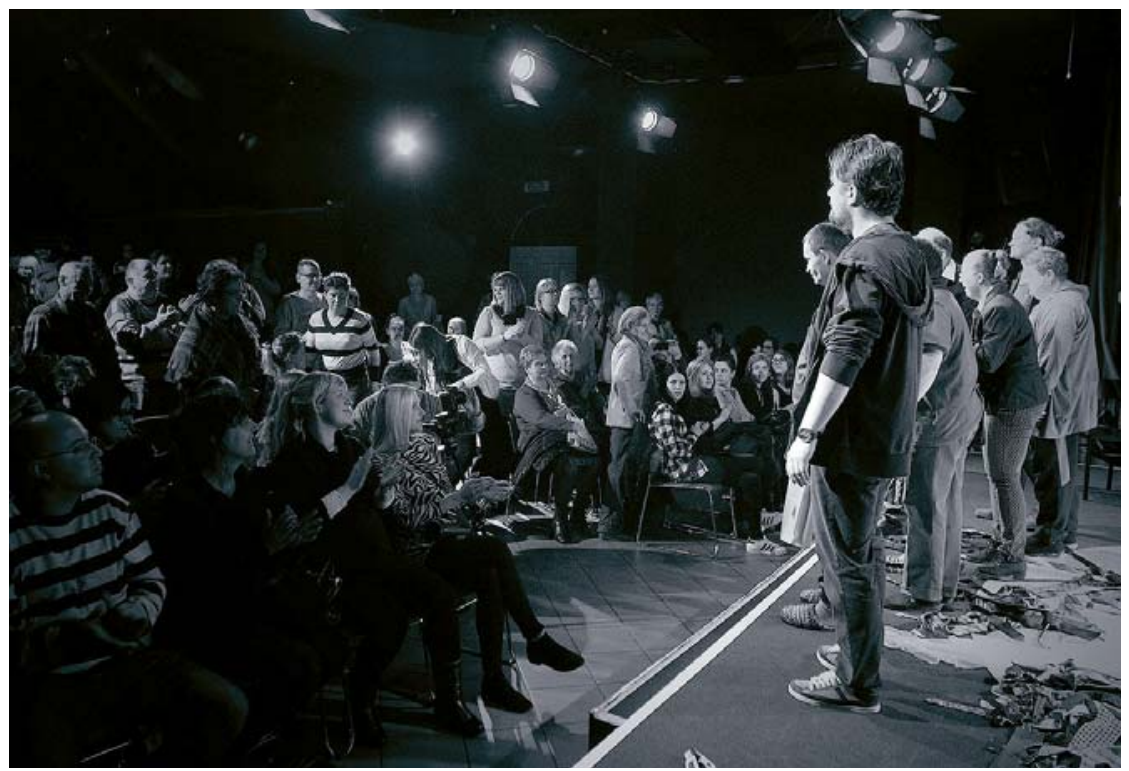

Photo 5. "My business" - premiere

Source: photo by Piotr Wittman. 
The project was supported and financed/funded by the Polish Ministry of Culture and Heritage. I had an honor and pleasure to be a part of the project: I was invited to be an expert acquainted with adulthood of people with intellectual disabilities, particularly interested and experienced in research devoted to being a couple.

It was the first time in Poland where actors with intellectual disabilities shared and performed on the stage with professional actors and other professionals and collaborated with each other while rehearsals and working on the performance. The experiment was a success and became a wonderful experience for all participants: Personal Office Items actors, professionals and the audience.

\section{3. "My business" - overcoming social stereotypes, beliefs and prejudices}

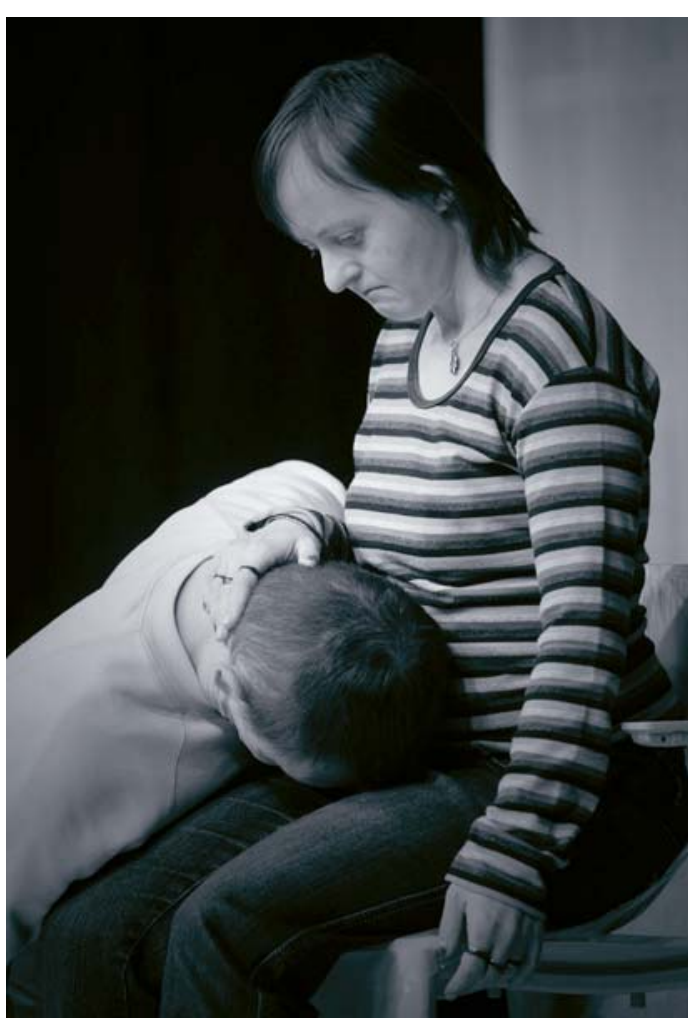

Photo 6. "My business" - rehearsals, Marzena Gajewska and Marcin Wenta Source: photo by Piotr Wittman.
The performance is devoted to the phenomenon of love, sexuality, motherhood/fatherhood or being mother or father as the experience or rather the lack of experience of people with intellectual disabilities. It's still appears a very intimate and delicate problem, socially rejected and unwanted which perpetually remains a taboo [e.g. Fornalik 2004, 2007; Grütz 2007; Izdebski 2005; Kijak 2010, 2016; Kościelska 2004; Krzemińska 2009, 2012; Żyta 2013] It turns out, however, that intellectual disability - despite all difficulties and limitations in functioning - does not mean disqualification of ability to emotions, feelings and needs which demand to be realized / satisfied in relation between woman and man and create a very important and meaningful experience for them. "My business" attempts to perform it on stage and makes 
the audience face the phenomenon and confront with (social and individual) stereotypes and prejudices. It provokes asking valid questions and challenge answers, which seems so far accurate and obvious.

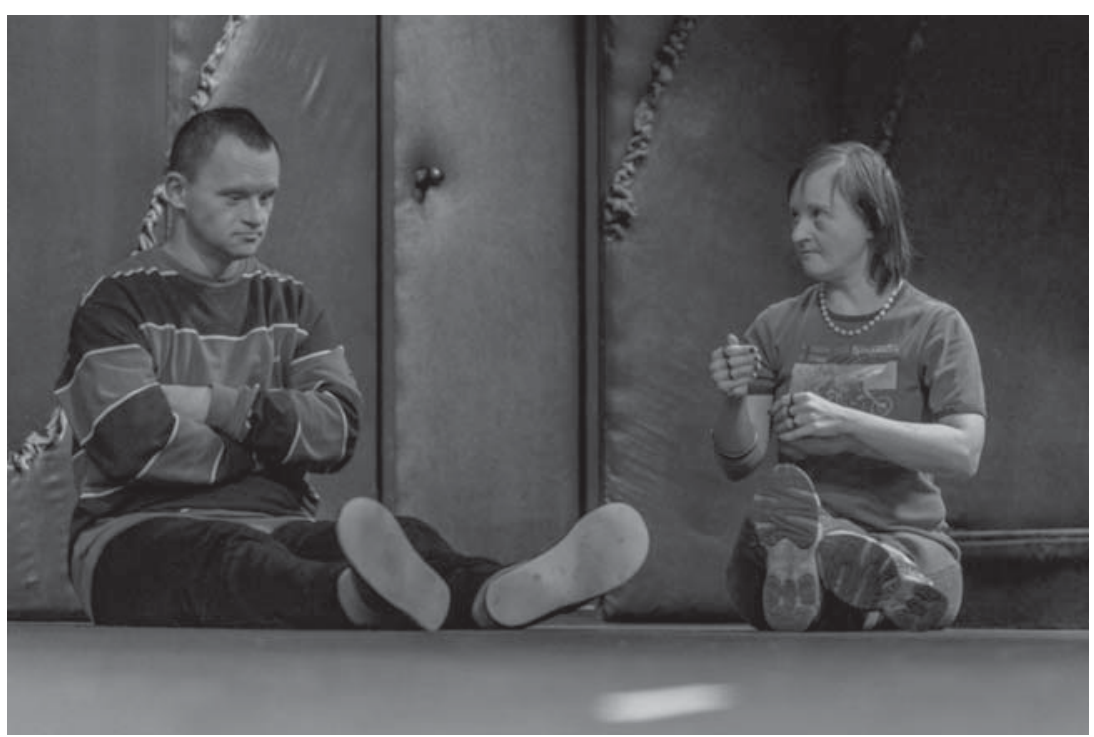

Photo 7. Rehearsing "My business". Marzena Gajewska as Wiktoria, Marcin Wenta as Adam Source: photo by Maciej Czarniak/trójmiasto.pl.

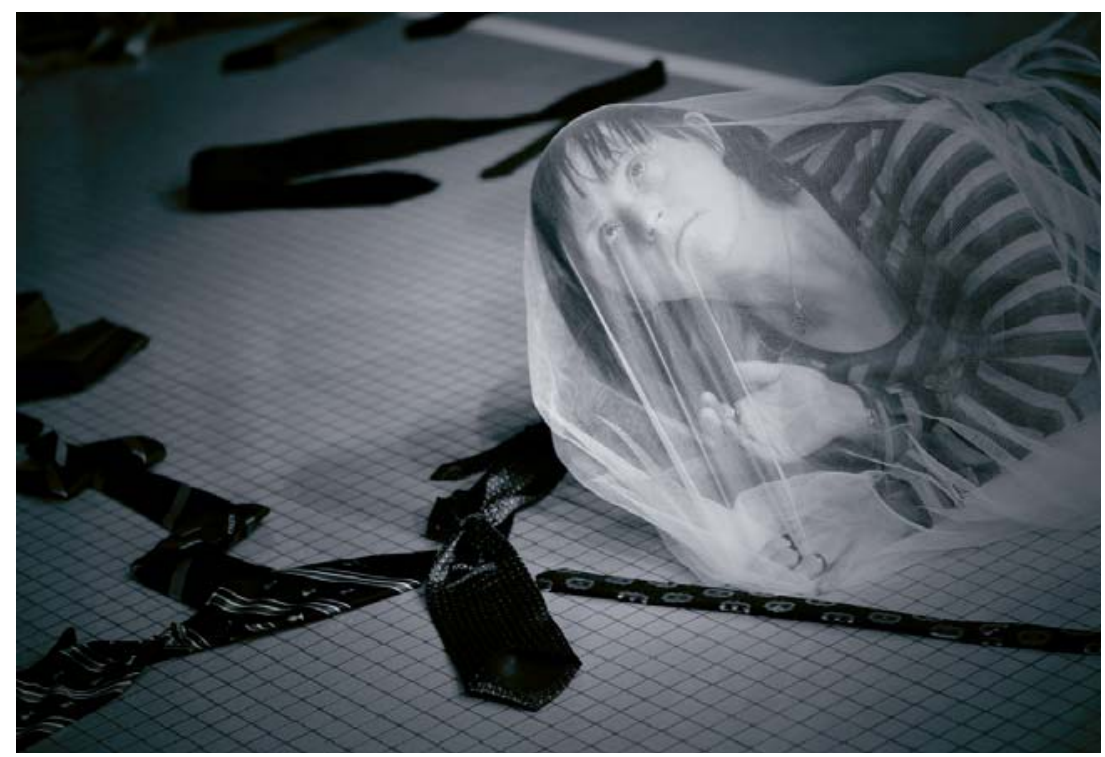

Photo 8. „My business” - rehearslas, Marzena Gajewska Source: photo by Piotr Wittman. 


\section{4. "My business" as art (creating)}

The performance "My business" is a momentous/ important artistic event. In a bold/ courageous and unprecedented way, it somehow "places" on the stage in a partner and symmetrical relationship professional actors and actors with intellectual disabilities and hence becomes an outstanding example of actions deconstructing the meanings ascribed to people with intellectual disabilities and art created by them. The performance itself, the problems it undertakes, the way actors with disabilities play the roles - suggestive, full of authenticity, reliable and realistic - it all resists infantilization of people with intellectual disabilities and depreciating social stereotypes linked with them. The performance itself and actors with intellectual disabilities challenge social beliefs to be worse, low competent and presupposed to undertake inferior and unmatched tasks and jobs. Performing on stage together with professional actors, people with intellectual disabilities successfully manage to appear creative and their acting expression undoubtfully appears attributing artistic values.

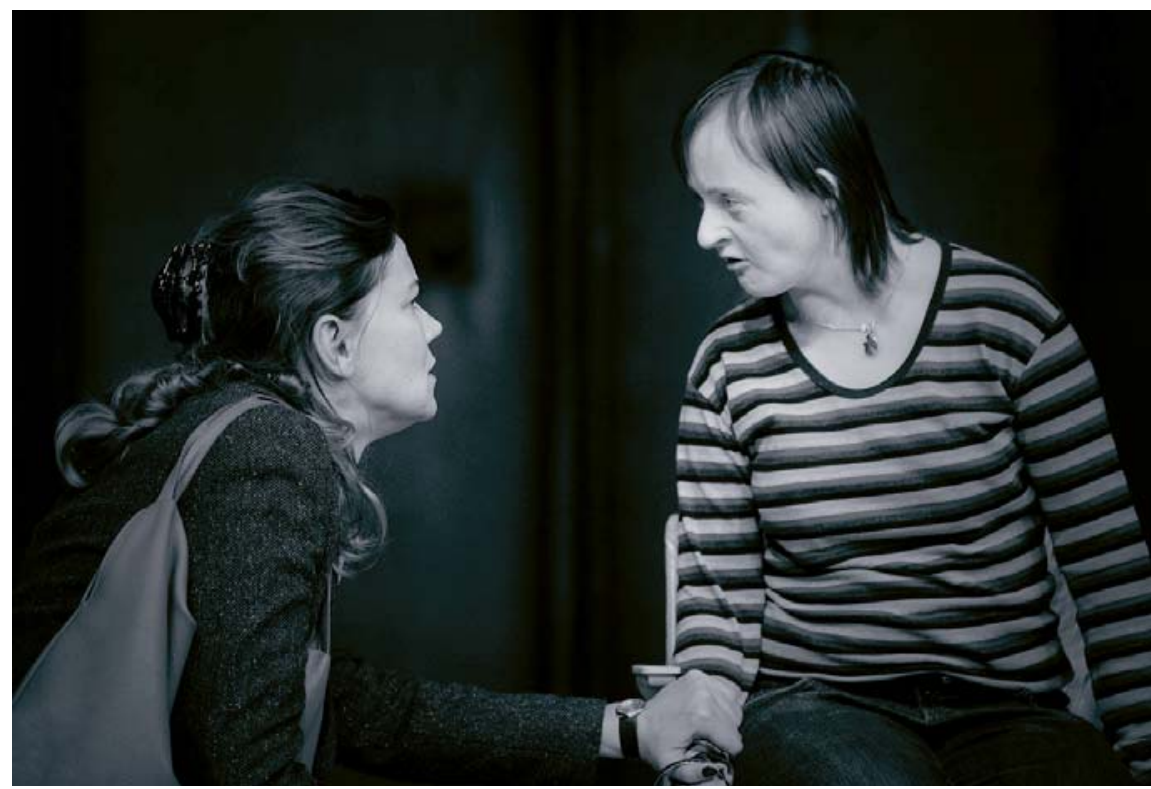

Photo 9. Aleksndra Nieśpielak as Mother, Marzena Gajewska as Wiktoria

Source: photo by Piotr Wittman. 


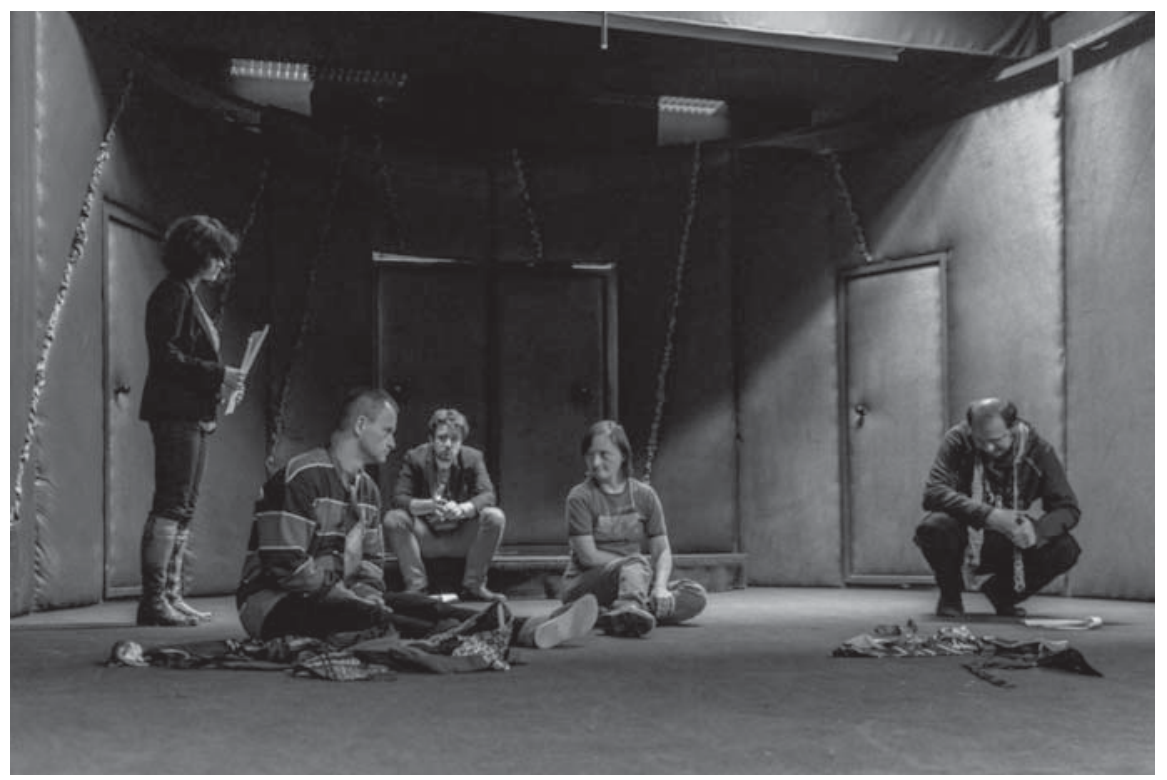

Photo 10. Rehearsing „My Business”. From the left: Iwona Siekierzyńska, Marcin Wenta, Krzysztof Grabowski, Marzena Gajewska, Adam Siekierzyński

Source: photo by Maciej Czarniak / trojmiasto.pl.

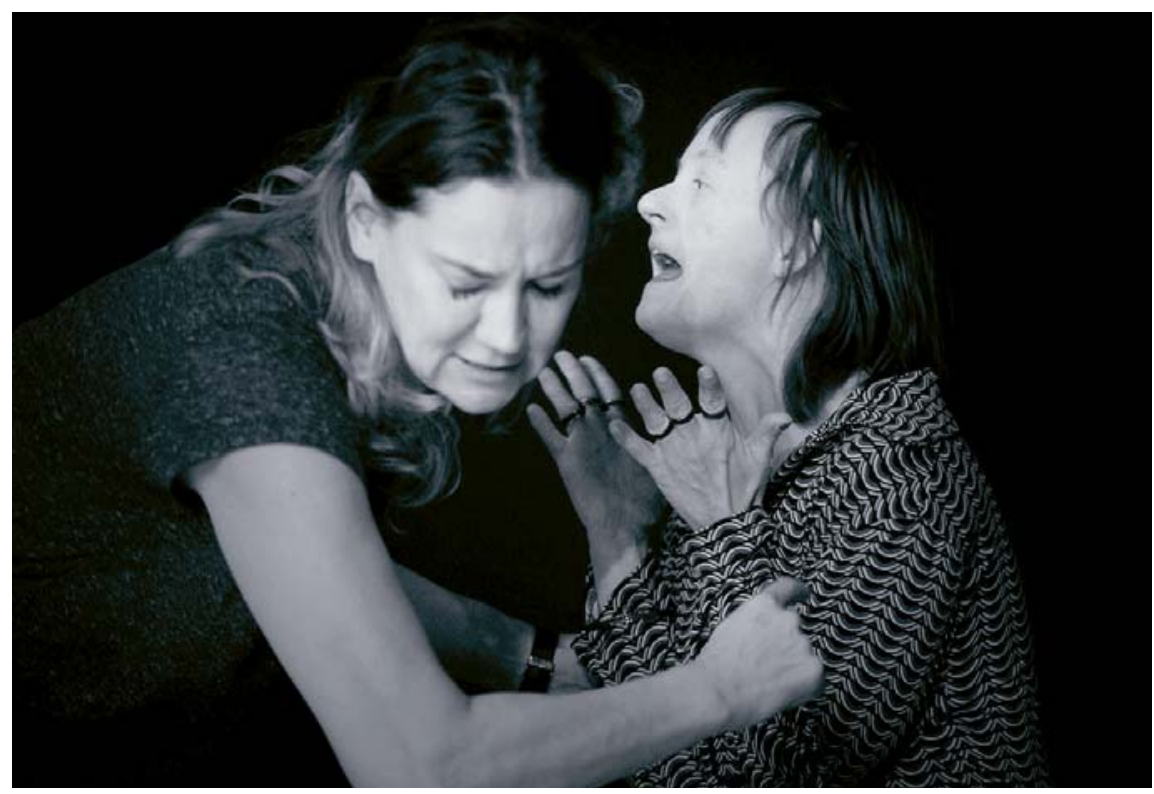

Photo 11. Aleksandra Nieśpielak as Mother, Marzena Gajewska as Wiktoria Source: photo by Piotr Wittman. 


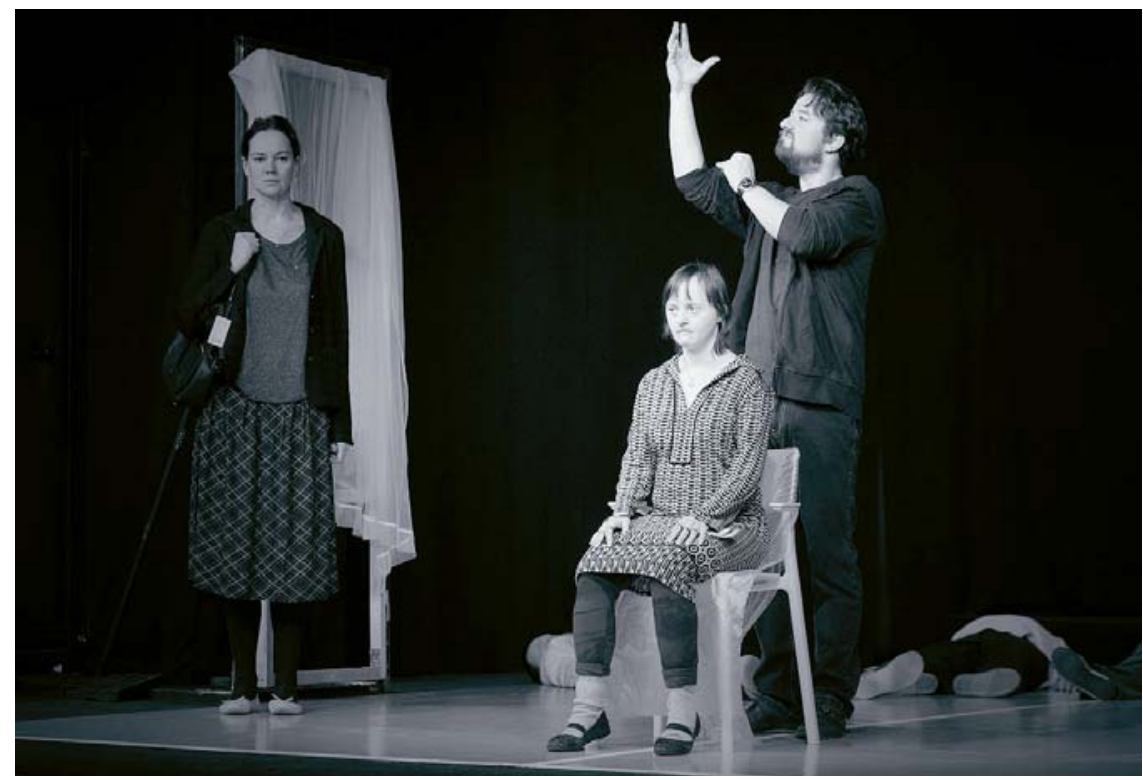

Photo 12. "My business" - rehearsals. Aleksandra Nieśpielak, Marzena Gajewska, Krzysztof Grabowski

Source: picture by Piotr Wittman.

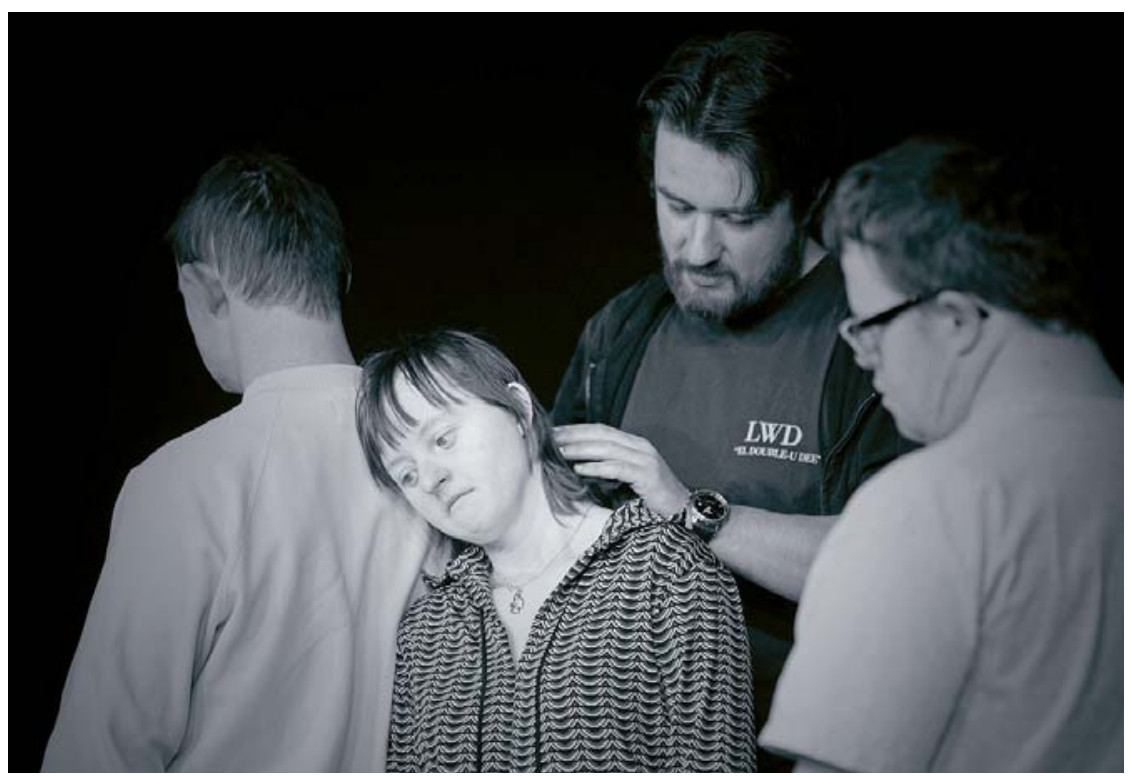

Photo 13. "My business" - rehearsals, Marcin Wenta, Marzena Gajewska, Krzysztof Grabowski, Tomasz Macniak

Source: photo by Piotr Wittman. 


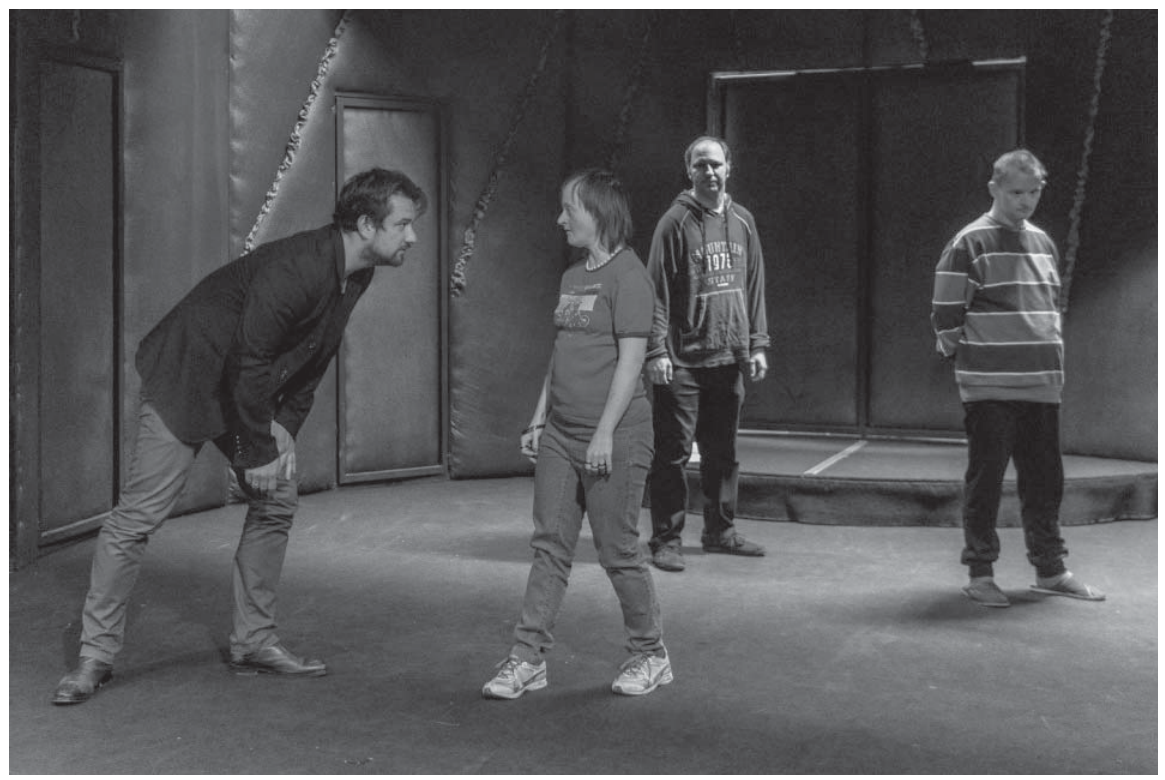

Photo 14. „My business” - rehearsals. From the left: Krzysztof Grabowski, Marzena Gajewska, Adam Siekierzyński, Marcin Wenta Source: picture by Maciej Czarniak / Trójmiasto.pl.

\section{5. "My business" as carnivalization / carnivalesque of Mikhail Bakhtin - theoretical approach}

"My business" is a performance in which actors with intellectual disabilities collaborate on stage with professionals and perform in front of the audience who usually faces and experiences disability in a very specific way. I find it possible to be discussed and reflected in reference to the concept of carnivalization and carnivalesque of Mikhail Bakhtin. The carnival for Bakhtin is an event in which all rules, inhibitions, restrictions and regulations which determine the course of everyday life are suspended - it especially denotes to a kind of disqualification and temporary rejection of all form of hierarchy in society. Bakhtin offers four categories of what he calls the "carnivalistic sense of the world" [http://culturalstudiesnow.blogspot.com/2011/07/mikhail-bakhtin-carnival-and.html], which I find useful to employ for analysing "My business".

The first category distinguished by Bakhtin is free and familiar interaction between people: in the carnival people, who are usually / normally separated can 
interact and express themselves to one another at ease [http://culturalstudiesnow.blogspot.com/2011/07/mikhail-bakhtin-carnival-and.html]. Applying this statement to the performance "My business" I could notice that actors with intellectual disability and professionals collaborate on stage and the audience participates in the spectacle performed by actors with disabilities - all this rarely or never happens in everyday life, in which typical form of hierarchy is a privileged position of normal people (either actors or the audience). Theatre and stage on which the performance goes on seems to become a space in which actors with intellectual disabilities play the roles whereas the audience - "normal" people are retreated to the position of spectator. It is the actor with intellectual disability, who at the same time becomes focal and distinguished. The performance enables the audience a specific contact and relationship with disabled people, which might not be otherwise experienced in every day life. According to Bakhtin, carnivalization makes the world and all traditional rules and hierarchy upside down: rulers become beggars, beggars play rulers. In a metaphorical sense: people with intellectual disabilities move to central and distinguished position and "normal" ones fail to be privileged and stay on margins. Yet paradoxically, carnivalistic sense of the world makes them both come closer and become more familiar and acquainted.

Looking at the theatre / stage and the performance through the lens of Bakhtin's carnivalization one may find it (a space of) a mutual communication and dialogue. Watching the performance, the audience follows what happens on the stage: experiences (of) the characters, their feelings, and emotions and re-discovers people with intellectual disabilities / Down Syndrome who appear to act and behave similarly to "the normal ones". It all makes circumstances to see people with intellectual disabilities in terms of humanity " [...] and it is also a call for fulfilling ethical obligations with emotional sensitivity towards the other. [...] Carnival is an essential part of the dialogic world, for it catalyzes new beginnings and keeps the system open-ended. If outsideness is an essential part of aesthetic consciousness, a periodic merger into the collective is an essential part of carnivalized consciousness, and together they keep the dialogue alive" - says Lakshmi Bandlamudi [http://balticworlds.com/wp-content/uploads/2010/02/BW-1-2-2017-BAKHTINTHEME.pdf]. The Other, initially supposed in a category of difference and strangeness, previously imagined to perform exclusively abnormal and specific, appears (more) human and shares similar and typical to all experiences. In carnival they all receive a chance for free and familiar interaction, initiating communication and dialogue that could become a starting point in becoming closer and change meanings ascribed to one another. Meanings changes, reflection, redefinition of what is normal/abnormal, able/disable and could be seen in the light of dualistic and ambivalent sens. According to Mikhail Bakhtin the carnival appears a metaphor of medieval consciousness in which the two remote and separate 
forms of life are linked: "On the one hand stood the normal, official, serious and gloomy everyday life which were subordinated to strict hierarchic order and full of terror and dogmatism. On the other hand there were the carnivalesque life which were free and unbounded, filled with ambivalent laughter, sacrilegious and the defilement of anything sacred, humiliations and familiar contact with everyone and everything. Both these life forms were legitimate, but they were separated by harsh temporal borders". [http://culturalstudiesnow.blogspot.com/ 2011/07/mikhail-bakhtin-carnival-and_22.html]. All this takes place on stage and within the audience while "My business" is going on: actors with intellectual disabilities act on stage with professionals and the "normal" audience watches the performance and becomes aquainted with the real life problems experienced by people with disabilities: their feelings, emotions, social context they live in, stereotypes, prejudices, attitudes, rejection, moral responsibilities, support, etc. It happens in a free and familiar interaction between "normal" people and people with disabilities, changing their relation towards more balanced and symmetric.

According to Bakhtin "The carnival [...] is a festival of time which exterminates all and renews all, [...] which expresses change the relativity of structure and order and the contingency of authority and hierarchic positions" [http://culturalstudiesnow.blogspot.com/2011/07/mikhail-bakhtin-carnival-and_22.html].

The second category proposed by Bakhtin describing carnivalesque is eccentric behaviour: "behaviour that was otherwise unacceptable is legitimate in carnival and human nature's hidden sides are revealed" [http://culturalstudiesnow. blogspot.com/2011/07/mikhail-bakhtin-carnival-and_22.html]. I dare say that being a couple with intellectual disabilities, relationship between woman and man with Down syndrome, falling in love, manage it all intellectually and emotionally and make their relationship work or to undertake the responsibilities and difficulties of life together - all this appears hardly acceptable and legitimate, as well as their sexual needs ( satisfaction) in the intimate and personal mutual relation and contacts. Society disagrees with love and sexuality of people with intellectual disabilities and even supposes behaviours connected with this sphere "eccentric" undesirable, embarrassing, odious, nasty and even perceives it abnormal or disgusting and hence makes adults with intellectual disabilities oppressed. They are not allowed to be "eccentric" this way. In "My business" the intimate, controversial and rejected phenomenon of love, sexuality, pregnancy of woman and man with Down syndrome is turned into light and performed on stage. A taboo is revealed and becomes somehow experienced by actors and audience. The spectators are in a way forced to confront with "eccentric behaviour" of people with Down Syndrome who perform their "nature's hidden sides" and eventually reflect on them and provoke the change of meanings ascribed to them. Eventually, it turns out that the Other - i.e. woman and man with Down Syndrome faces the 
same problems, feelings, emotions, needs, desires and experience the world in a quite similar way - as V. Sukovata concludes [http://balticworlds.com/wp-content/uploads/2010/02/BW-1-2-2017-BAKHTIN-THEME.pdf]: "According to Bakhtin, the carnival is a system of producing new subjectivities that do not belong in the realm of 'normalcy'."

Carnivalistic misalliances - the third of categories distinguished by Bakhtin: "the free and familiar attitude of the carnival enables everything which is normally separated to connect - the sacred with the profane, the new and old, the high and low etc." [http://culturalstudiesnow.blogspot.com/2011/07/mikhail-bakhtincarnival-and_22.html]. "My business" - links / connects [and makes (more) familiar] ability and disability, people with disabilities and normal ones, the two remote / separate worlds are merging with one another, being recognizable or more related, allowed for different ways of approaching disability and living with it. Furthermore, "the carnival unites the two poles of change and crisis, birth and death, old and young, down and up, wisdom and stupidity etc. the dualistic imagery is characteristic of the carnival for their contradiction." [http://culturalstudiesnow. blogspot.com/2011/07/mikhail-bakhtin-carnival-and_22.html]. Performing on stage actor with Down Syndrome/intellectual disability "turns into the king" and makes "normal" audience and actors confused: it turns out that special needs adults, who are usually supposed to be disabled, weak, uncapable, who may lack common sense and usually imagined to behave strange, dangerous, abnormal - they are able to undertake tasks and successfully perform on stage, participating in cocreating art and be a part of it. What the performance also emphasises is the main theme: it undertakes a very intimate and complicated problem and proves people with intellectual disabilities do experience love, sexual needs, intimacy and try to cope with and manage all that matters nevertheless social and cultural oppression.

Sacrilegious is the forth category distinguished by Bakhtin to describe carnival: "the carnival for Bakhtin is a site of ungodliness, of blasphemy, profanity and parodies on things that are sacred. [http://culturalstudiesnow.blogspot.com/ 2011/07/mikhail-bakhtin-carnival-and_22.html]. "My Business" appears desacralizing (of) normality and being competent, disqualifies ideas and concepts of what is normal and legitimate; who may fall in love and make sex or who may participate and create art and culture. For me, it refers to two aspects: artistic and breaking the taboo and stereotypes connected with relationship between women and men with intellectual disabilities. Despite the fact that "in our society, carnival and the grotesque do not have the same meaning than they used to have but still, these concept help us to understand what is problematic in our culture. These concepts still exist in our society, in a fragmented and localised form" [http:// www.communicationinterne.net/bakhtin-carnival-theory/]. (Living with) intellectual disabilities perpetually remains troublesome problem undergoing social 
and cultural oppression. Theatre, where the performance is going on, if referred to the carnivalesque idea becomes universal and belonging to all people. It creates a space in which boundaries could be crossed and the meanings ascribed to people with intellectual disabilities changed. "My business" appears a forerunning and outstanding performance about love, relationship, sexual needs, pregnancy in the experience of adults with Down Syndrome/intellectual disabilities who live in a particular family, institutional and social context. It highlights some valid questions referring to their place in society and to their creative output - participating and co-creating culture, opening space to redefinitions and changing meanings which could be negotiated and altered.

\section{References}

Bachtin M. (1970), Problemy poetyki Dostojewskiego, PIW, Warszawa.

Bugros Mclean P., Wallace D. (2013), Blogging the Unspeakable: Racial Politics, Bakhtin, and the Carnivalesque, „International Journal of Communication”, no. 7, s. 1518-1537, https://ijoc.org/index.php/ijoc/article/viewFile/1698/947.

Dentith S. (1995), Bakhtinian Thought: An introductory reader, Routledge.

Fornalik I. (2004), Dorosłość pod ochronq̨? Seksualność osób z głębsza niepetnosprawnościq intelektualna we wczesnej dorostości [w:] Człowiek niepetnosprawny w rożnych fazach życia, J. Bąbka (red.), Wydawnictwo Akademickie „Żak”, Warszawa.

Fornalik I. (2007), Miłość, seks i prokreacja jako wartości w dorostym życiu osób z niepetnosprawnościq intelektualnq [w:] O seksualności osób niepetnosprawnych, A. Ostrowska (red.), IRSS, Warszawa.

Grütz M. (2007), Trzy historie o miłości rehabilitującej. Partnerstwo, małżeństwo i rodzicielstwo $w$ życiu niepełnosprawnych intelektualnie mieszkańców domu pomocy społecznej [w:] Osoba z niepetnosprawnościq w systemie rehabilitacji, edukacji i wsparcia społecznego, Cz. Kosakowski, A. Krause, A. Żyta (red.), Wydawnictwo Uniwersytetu Warmińsko-Mazurskiego, Olsztyn.

Izdebski Z. (2005), Postawy Polaków wobec seksualności osób niepetnosprawnych ruchowo i intelektualnie [w:] Seksualność osób z niepetnosprawnościa intelektualna - uwalnianie od schematów i uprzedzeń, J. Głodkowska, A. Giryński (red.), APS, Warszawa.

Kijak R. (2017), Dorośli z głębszq niepetnosprawnościq intelektualna jako partnerzy, matżonkowie i rodzice, Oficyna Wydawnicza „Impuls”, Kraków.

Kościelska M. (2004), Niechciana seksualność. O ludzkich potrzebach osób niepetnosprawnych intelektualnie, Wydawnictwo Jacek Santorski \& Co., Warszawa.

Krzemińska D. (2009), O byciu parq osób z niepetnosprawnościq intelektualnq, „Niepełnosprawność" nr 2.

Krzemińska D. (2012), "Jak go widzę, to szatu dostaję na jego punkcie!”. Miłość w narracjach par osób z niepetnosprawnościq intelektualna [w:] Wokót dorosłości z niepetnosprawnościq intelektualna. Teksty rozproszone, D. Krzemińska, I. Lindyberg, Oficyna Wydawnicza „Impuls”, Kraków

Żyta A. (2013), Małżeństwa i rodzicielstwo osób z niepełnosprawnościq intelektualną - wyzwania, „Edukacja Dorosłych”, nr 2. 


\section{Netnography}

http://balticworlds.com/wp-content/uploads/2010/02/BW-1-2-2017-BAKHTIN-THEME.pdf. http://culturalstudiesnow.blogspot.com/2011/07/mikhail-bakhtin-carnival-and_22.html. http://www.communicationinterne.net/bakhtin-carnival-theory/. http://balticworlds.com/wp-content/uploads/2010/02/BW-1-2-2017-BAKHTIN-THEME.pdf. 